\title{
Comparing Vegetative Propagation of Two 'Schipkaensis' Common Cherrylaurel Ploidy Levels
}

\author{
Justin A. Schulze, Ryan N. Contreras ${ }^{1,3,4}$, and Carolyn F. Scagel ${ }^{2}$
}

AdDitional INDEX wORDs. polyploidy, Prunus laurocerasus, semi-hardwood cuttings, IBA, NAA

\begin{abstract}
Summary. 'Schipkaensis' common cherrylaurel (Prunus laurocerasus) is an important nursery crop across the United States. In our breeding efforts to reduce shothole symptoms and weediness, we have created chromosome doubled forms of this cultivar. Vegetative propagation is an important factor in nursery production, and we have found no studies that have looked at comparative adventitious rooting of stem cuttings using induced polyploids. The objective of this research was to determine if rooting ability varied between these two ploidy levels. Semihardwood stem cuttings from wild-type $(22 x)$ and polyploid $(44 x)$ ploidy levels were taken at the end of July 2015 and the beginning of July 2016. Cuttings were dipped in $1030 \mathrm{ppm}$ $(0.10 \%)$ indole-3-butyric acid (IBA) and $660 \mathrm{ppm}(0.066 \%) 1$-naphthaleneacetic acid (NAA) before being set in rooting substrate. After 1 month, cuttings were removed from substrate and data collected. Data included; rooting percentage, root number per rooted cutting, average root length, and total root length. In $2015,88 \%$ of the cuttings from the $44 x$ plants and $63 \%$ of the cuttings from the $22 x$ plants rooted. In $2016,100 \%$ of cuttings from both ploidy levels rooted. In both years, average root length and total root length were similar between ploidy levels; however, cuttings from $22 x$ plants generally had more roots than those from $44 x$. Chromosome-doubled 'Schipkaensis' common cherrylaurel rooted effectively, and produce transplantable cuttings similar to the standard ploidy.
\end{abstract}

$\mathrm{C}$ ommon cherrylaurel is a species of evergreen stone fruit native from eastern Europe to southwest Asia. In some parts of the Mediterranean, this species is grown for food and medicinal purposes (Kolayli et al., 2003). In the United States and Europe, cultivars of this species are common ornamental landscape plants. Popular compact cultivars include; Mount Vernon, Otto Luyken, Schipkaensis, and Zabeliana. Many cultivars are susceptible to bacterial and

This article is a portion of a thesis submitted by J. Schulze in partial fulfillment of requirements for a M.S. The authors appreciate the-kind support of plant materials from Blue Heron Farm in Corvallis, OR

We would like to acknowledge Oregon Association of Nurseries for partial funding of this research.

Mention of trade names or commercial products in this publication is solely for the purpose of providing specific information and does not imply recommendation or endorsement by the U.S. Department of Agriculture. USDA is an equal opportunity provider and employer.

${ }^{1}$ Oregon State University, Department of Horticulture, 4017 Agricultural and Life Sciences Building, Corvallis, OR 97331

${ }^{2}$ U.S. Department of Agriculture, Agricultural Research Service, Horticultural Crops Research Unit, 3420 NW Orchard Avenue, Corvallis, OR 97330

${ }^{3}$ Associate Professor of Horticulture.

${ }^{4}$ Corresponding author. E-mail: ryan.contreras@ oregonstate.edu.

doi: 10.21273/HORTTECH03600-16 fungal pathogens that cause shothole disease [e.g., Pseudomonas syringae pv. syringae, Xanthomonas arboricola pv. pruni, Wilsonomyces carpophilus, Microgloeum pruni, and Cercospora sp. (De Boer, 1980; Marchi et al., 2014; Pscheidt and Ocamb, 2014; Williams-Woodward, 1998)]. Shothole disease presents with numerous small circular holes in the leaves of plants, these holes are caused by loss of necrotic leaf tissue in areas killed by pathogens. This can greatly reduce ornamental appeal, and in severe cases, cankers that girdle stems may kill infected plants. Due to abundant fruit production, this species has become naturalized across areas of the North American west coast (U.S. Department of Agriculture, 2006), and in other regions is considered invasive (Hättenschwiler and Körner, 2003).

In attempts to address shot-hole symptoms and the weedy tendencies in this species, we created chromosome doubled forms of the cultivar Schipkaensis. Although many studies have compared morphological variability in ploidy series (Huang et al., 2015; Kermani et al., 2003; Li et al., 1996; Ulrich and Ewald, 2014), we have found none that addressed adventitious rooting of stem cuttings. Successful vegetative propagation is an important consideration in determining plant potential for large-scale production (Hartmann et al., 2011). We wanted to assess if alteration in ploidy level had an effect on vegetative propagation of this plant.

Previous research seeking to optimize vegetative propagation of common cherrylaurel successfully rooted hardwood cuttings at high percentages (Ribeiro et al., 2010; Sülüşoğlu and Çavuşoğlu, 2009; Yazici, 2009). Ribeiro et al. (2010) reported exogenous application of IBA improved rooting percentage compared with a control without IBA, but IBA ranging from 1000 to $7500 \mathrm{ppm}(0.1 \%$ to $0.75 \%)$ produced no statistically significant difference among treatments. Other sources report taking semihardwood cuttings in summer is also effective (Adams, 1983; Dirr, 2009; Sülüşoğlu and Çavuşoğlu, 2010). The cultivar Schipkaensis, in particular, has been reported to root as quickly as 3 weeks (Adams, 1983). Our objective was to determine if rooting percentage and other root traits vary between natural $[2 n=22 x=176$ (Meurman, 1929)] and chromosome doubled $(2 n=44 x=352)$ ploidy levels of 'Schipkaensis' common cherrylaurel.

\section{Materials and methods}

Plant material. In 2015, standard ploidy level $(22 x)$ 'Schipkaensis' common cherrylaurel material was

\begin{tabular}{llll}
\hline $\begin{array}{l}\text { Units } \\
\text { To convert U.S. to SI, } \\
\text { multiply by }\end{array}$ & U.S. unit & SI unit & $\begin{array}{l}\text { To convert SI to U.S., } \\
\text { multiply by }\end{array}$ \\
\hline 3.7854 & gal & $\mathrm{L}$ & 0.2642 \\
2.54 & inch(es) & $\mathrm{cm}$ & 0.3937 \\
25.4 & inch $(\mathrm{es})$ & $\mathrm{mm}$ & 0.0394 \\
0.0254 & mil & $\mathrm{mm}$ & 39.3701 \\
28.3495 & $\mathrm{oz}$ & $\mathrm{g}$ & 0.0353 \\
1 & $\mathrm{ppm}$ & $\mathrm{mg} \cdot \mathrm{L}^{-1}$ & 1 \\
$\left({ }^{\circ} \mathrm{F}-32\right) \div 1.8$ & ${ }^{\circ} \mathrm{F}$ & ${ }^{\circ} \mathrm{C}$ & $\left({ }^{\circ} \mathrm{C} \times 1.8\right)+32$
\end{tabular}


collected from 3-year-old commercially grown plants (Blue Heron Farms, Corvallis, OR) growing in 3 -gal containers. Chromosome doubled $(44 x)$ plant material was confirmed via flow cytometry (Contreras and Meneghelli, 2016), and collected from three 3-year-old plants growing in 7-gal containers containing a soilless fir-bark substrate. The $44 x$ plants received $20 \mathrm{~N}-4.4 \mathrm{P}-8.3 \mathrm{~K}$, controlledrelease fertilizer (Apex ${ }^{\circledR}$ Evergreen; J.R. Simplot, Boise, ID) at a rate of $32 \mathrm{~g}$ per container annually in April. All $44 x$ plants were under overhead irrigation twice per day for $40 \mathrm{~min}$ when cuttings were collected. In 2016, cuttings were collected from the previous year's rooted cuttings ( 1 year old) growing in 3-gal containers, under the irrigation and fertility conditions previously stated. All plants in both years were grown on outdoor container pads in full sun.

Cutting treatments. On 29 July 2015 and 5 July 2016, 24 cuttings from each ploidy level were taken. Cuttings were 7 to $10 \mathrm{~cm}$ long with three to five nodes. The three youngest leaves were retained on cuttings and any remaining leaves were removed. Retained leaves were bisected to reduce water loss. The basal $5 \mathrm{~cm}$ of cuttings were dipped for $10 \mathrm{~s}$ in $1030 \mathrm{ppm}$ IBA $(0.1 \%)$ and $660 \mathrm{ppm}(0.066 \%)$ NAA dissolved in 9.8\% isopropyl alcohol (Woods Rooting Compound; Earth Science Products, Wilsonville, OR) and the lower 3 to $5 \mathrm{~cm}$ of each cutting was inserted into 4 -inch square containers (Gauge 400s; Merrill's Packaging, Burlingame, CA) filled with two perlite (Supreme Perlite, Portland, OR): one soilless substrate (Metro-Mix 840PC; Sun Gro Horticulture, Agawam, MA) by volume. Each year, the 48 cuttings were randomly arranged in three 17-inch square flats, with eight replicates from each ploidy level in a flat. Flats were placed in a clear 6-mil polyurethane mist-tent with bottom heat $\left(78{ }^{\circ} \mathrm{F}\right)$ under intermittent mist (30 s every $30 \mathrm{~min}$ from $0600 \mathrm{HR}$ to $2000 \mathrm{HR}$ ) for 1 month. The misttent was located in a glass-house covered with a $50 \%$ shadecloth and temperatures set to $75 / 65^{\circ} \mathrm{F}$ day/ night. The glass-house was located on the campus of Oregon State University in Corvallis.

Rooting evaluation. Cuttings were removed from the substrate, and rinsed gently with water to remove remaining substrate. Cuttings were placed on a flat surface and the roots were manually spread apart. Roots on each cutting were measured using a standard metric ruler to the nearest millimeter. Number of roots and length of each root on all rooted cuttings were measured if the root was over $2.0 \mathrm{~mm}$ long. The total root length and average root length was calculated per cutting.

Data Analysis. Data were analyzed using R-studio, version 3.1.1 (R Foundation for Statistical Computing, Vienna, Austria). The experimental design was a randomized complete block design with replication. Due to lack of normality and unequal variance, rooting percentages were compared using the nonparametric Kruskal-Wallis rank sum test. Year and ploidy were evaluated separately, with flats as experimental
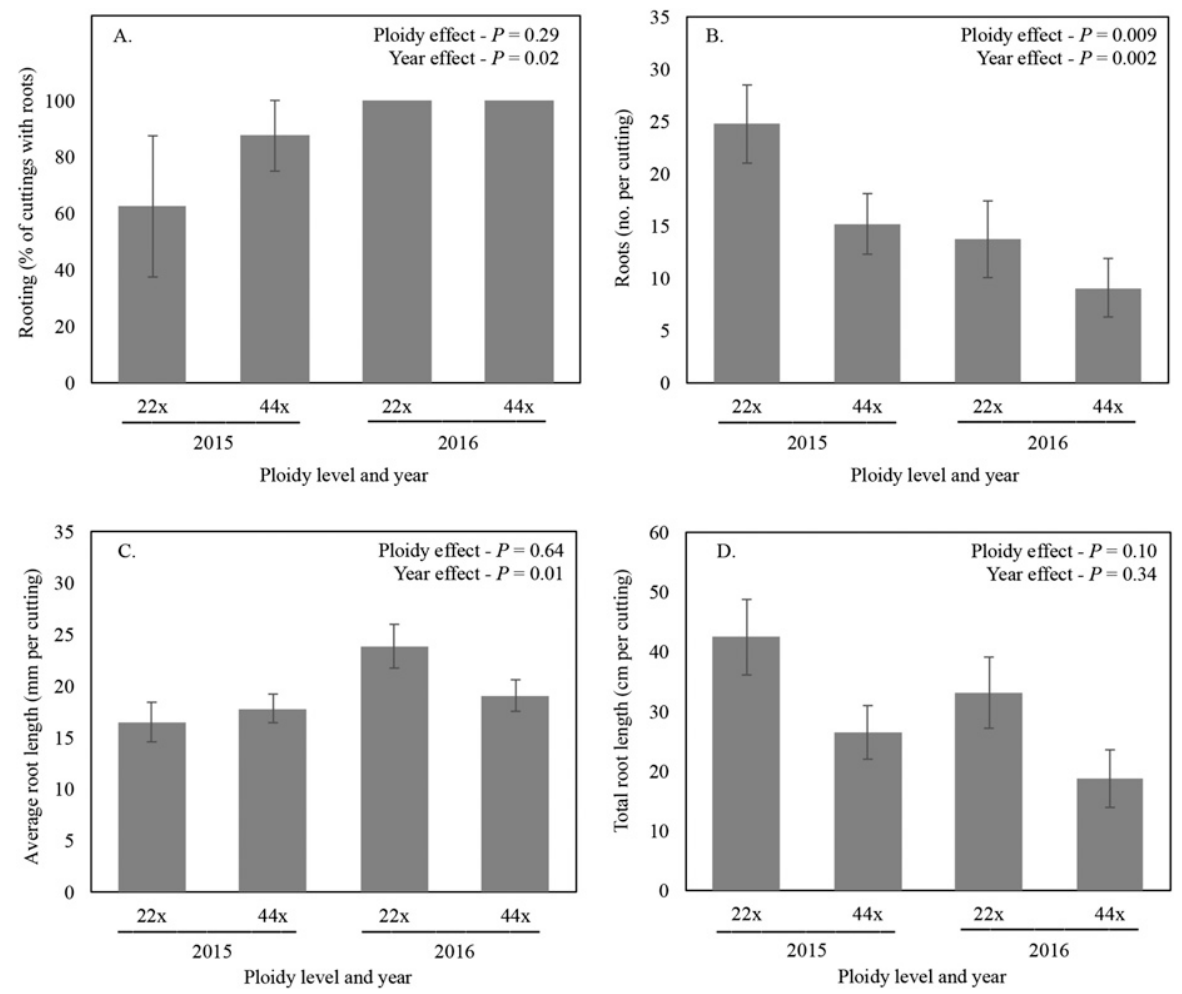

Fig. 1. Adventitious rooting, average root length, root number, and total root length on stem cuttings from $22 x$ and $44 x$ 'Schipkaensis' common cherrylaurel. Cuttings were taken in late July 2015 and in early July 2016. (A) Column means and SE bars based on Kruskal-Wallis rank sum test $(n=6) .(B, C, D)$ Unrooted samples in 2015 resulting in variable sample size [2015 $22 x(\mathrm{n}=15), 201544 x$ $(\mathrm{n}=21), 201622 x(\mathrm{n}=24), 201644 x(\mathrm{n}=24)]$. (B, D) Probability for ploidy and year are for main effects from analysis of variance (ANOVA), using transformed variables. Columns are back-transformed means and error bars are one SE of the mean. (C) Probability values for ploidy and year are for main effects from ANOVA. Columns are least squares (LS) means and error bars are one SE of LS means; $1 \mathrm{~mm}=0.0394$ inch, $1 \mathrm{~cm}=0.3937$ inch . 
the $44 x$ rooted, but the variability among replicates was high resulting in similar rooting between $44 x$ and $22 x$ plants. All cuttings rooted in 2016. Previous research of wild-type common cherrylaurel cuttings resulted in rooting between $60 \%$ and $88 \%$, when IBA was used (Ribeiro et al., 2010; Sülüşoğlu and Çavuşoğlu, 2009, $2010)$. Our results are consistent with Dirr (2009), who reports up to $100 \%$ rooting in semihardwood cuttings taken in summer.

Increased ploidy decreased the number of roots produced by cuttings (Fig. 1B). On average, cuttings from $22 x$ plants produced 21 roots and $44 x$ plants produced 13 roots, representing a $38 \%$ decrease in root number. Having fewer roots could have a detrimental effect on water and nutrient absorption. However, in our study we applied only one concentration of IBA and NAA. Sülüşoğlu and Çavuşoğlu (2010) show an increase in number of roots from 1000 to $2000 \mathrm{ppm}(0.2 \%)$ IBA, and then subsequent decrease in root number from 2000 to $8000 \mathrm{ppm}$ $(0.2 \%$ to $0.8 \%)$ IBA. The $44 x$ plants may have different requirements for optimal rooting compared with $22 x$, and perhaps altering auxin concentrations could improve the root number on $44 x$ cuttings. Root number also varied by year, suggesting sensitivity to factors other than auxin-concentration and ploidy, such as collection time. In previous studies, collection time appears to affect root number per cutting in this species. Hardwood cuttings taken in March (Sülüşoğlu and Çavuşoğlu, 2009), and semihardwood cuttings taken in July (Sülüşoğlu and Çavuşoğlu, 2010), both treated with $2000(0.2 \%) \mathrm{ppm} \mathrm{IBA}$, produced an average of 55.0 and 22.2 roots per rooted cutting, respectively.

Ploidy did not influence average root length (Fig. 1C). Average root length of cuttings from $22 x$ plants $(20.2 \mathrm{~mm})$ were similar to that of $44 x$ plants $(18.5 \mathrm{~mm})$ for both years. However, average root length in 2016 was $25 \%$ greater than in 2015 . This suggests that collection timing may affect average root length as well as number of roots per cutting. Compared with our results, Sülüşoğlu and Çavuşoğlu (2010) reported longer average root length (42.2 to 62.6 $\mathrm{mm}$ ) on cuttings of wild-type common cherrylaurel evaluated after $90 \mathrm{~d}$.

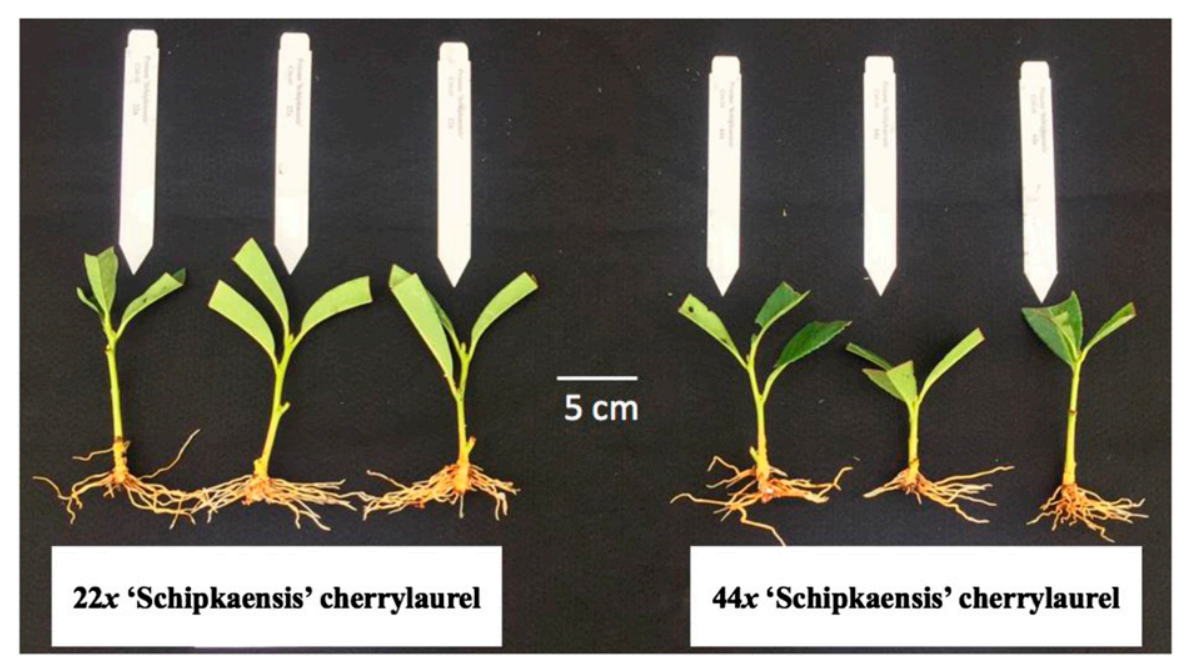

Fig. 2. Rooted stem cuttings from $22 x$ and $44 x$ ploidy levels of

'Schipkaensis'common cherrylaurel. This photo was taken of 2016 cuttings that measured the highest in the category "total root length" from each block; $1 \mathrm{~cm}=$ 0.3937 inch.

It is likely that increasing time to evaluation would also increase our average root length.

Total root length per cutting did not differ between years (Fig. 1D). On average, total root length on cuttings from $22 x$ plants $(37.8 \mathrm{~cm})$ was greater than total root length on cuttings from $44 x$ plants $(22.6 \mathrm{~cm})$, but this difference was not statistically significant.

Our study confirmed the chromosome doubled form of 'Schipkaensis' common cherrylaurel roots at a sufficiently high percentage and produces transplantable cuttings (Fig. 2). Compared with the $22 x$ ploidy level, the $44 x$ produced fewer roots, but this difference is not likely commercially important. Visually, the root systems on cuttings of both ploidy levels were coarse with no branching or fine root development. Roots of $44 x$ cuttings did appear slightly thicker, but we did not measure root diameter or determine root dry weight. Future studies should include these factors when assessing differences in rooting among treatments. All rooted cuttings have been successfully transplanted into larger containers, and we have seen no negative effects of reduced root number, even though the $44 x$ cuttings produced nearly 10 and five fewer roots per cutting in 2015 and 2016, respectively. As propagation can be a bottleneck for production, it is important to ensure that new cultivars are able to be propagated efficiently. In our study, there were no apparent detrimental effects to rooting cuttings of 'Schipkaensis' common cherrylaurel following induction of higher-level polyploids.

\section{Literature cited}

Adams, G. 1983. Propagation and cultivation of Prunus laurocerasus 'Schipkaensis'. Intl. Plant Propagators'. Soc. Comb. Proc. 33:547.

Contreras, R.N. and L. Meneghelli. 2016. In vitro chromosome doubling of Prunus laurocerasus 'Otto Luyken' and 'Schipkaensis'. HortScience (In press).

De Boer, S.H. 1980. Leaf spot of cherry laurel caused by Psendomonas syringae. Can. J. Plant Pathol. 2:235-238.

Dirr, M.A. 2009. Manual of woody landscape plants: Their identification, ornamental characteristics, culture propagation and uses. Stipes Publ., Champaign, IL.

Hättenschwiler, S. and C. Körner. 2003. Does elevated $\mathrm{CO} 2$ facilitate naturalization of the non-indigenous Prunus lauroceracus in Swiss temperate forests? Funct. Ecol. 17:778-785.

Hartmann, H.T., D.E. Kester, F.T. Davies, Jr., and R.L. Geneve. 2011. Hartmann and Kester's plant propagation: Principles and practices. 8th ed. Prentice Hall, Upper Saddle River, NJ.

Huang, R., D. Liu, M. Zhao, Z. Li, M. Li, and S. Sui. 2015. Artificially induced polyploidization in Lobularia maritima (L.) Desv. and its effect on morphological traits. HortScience 50:636-639.

Kermani, M.J., V. Sarasan, A.V. Roberts, K. Yokoya, J. Wentworth, and V.K. Sieber. 


\section{Research Reports}

2003. Oryzalin-induced chromosome doubling in Rosa and its effect on plant morphology and pollen viability. Theor. Appl. Genet. 107:1195-1200.

Kolayli, S., M. Küçük, C. Duran, F. Candan, and B. Dinçer. 2003. Chemical and antioxidant properties of Laurocerasus officinalis Roem. (cherry laurel) fruit grown in the Black Sea region. J. Agr. Food Chem. 51:7489-7494.

Li, W.L., G.P. Berlyn, and P.M.S. Ashton. 1996. Polyploids and their structural and physiological characteristics relative to water deficit in Betula papyrifera (Betulaceae). Amer. J. Bot. 83:15-20.

Marchi, G., T. Cinelli, and G. Surico. 2014. Bacterial leaf spot caused by the quarantine pathogen Xanthomonas arboricola pv. pruni on cherry laurel in central Italy. Plant Dis. 98:1600 (abstr.).
Meurman, O. 1929. Prunus laurocerasus L. a species showing high polyploidy. J. Genet. 21:85-94.

Pscheidt, J.W. and C.M. Ocamb (eds.). 2014. Pacific Northwest plant disease management handbook. Oregon State Univ., Corvallis.

Ribeiro, M.M., L.M. Collado, and M.A. Antunes. 2010. The influence of indole3-butyric-acid in Prunus laurocerasus vegetative propagation. Acta Hort. 885: 277-283.

Sülüşoğlu, M. and A. Çavuşoğlu. 2009. Cutting propagation possibilities of natural cherry laurel (Prunus laurocerasus L.) of Turkey. Amer-Eurasian J. Sustainable Agr. 3:234-237.
Sülüşoğlu, M. and A. Çavuşoğlu. 2010. Vegetative propagation of cherry laurel (Prunus laurocerasus L.) using semihardwood cuttings. Afr. J. Agr. Res. 5: 3196-3202.

U.S. Department of Agriculture. 2006. Prunus laurocerasus L. cherry laurel. 1 Sept. 2016. <http://plants.usda.gov/ core $/$ profile? symbol=PRLA5 $>$.

Ulrich, K. and D. Ewald. 2014. Breeding triploid aspen and poplar clones for biomass production. Silvae Genet. 63:47-58.

Williams-Woodward, J.L. 1998. Effect of fungicide treatment to control shot-hole disease of cherry laurel. 10 Mar. 2015. <http://www.canr.org/98013.pdf>.

Yazici, K., B. Dal, S. Gozlekci, L. Kaynak, and N. Ersoy. 2009. Effects of cutting type and duration time on rooting of three cherry laurel (Prunus laurocerasus L.) genotypes. Acta Hort. 818:199-204. 